\title{
Effects of some microelements on antifungal activity and biomass of the Actinomyces producing Validamycin-A
}

\author{
Nghiên cưu ảnh hưởng của một số nguyên tố vi lượng đến hoạt tính kháng nấm \\ và sinh khối của xạ khuẩn sinh kháng sinh Validamycin-A \\ Research article
}

Luong Huu Thanh ${ }^{1}$, Vu Thuy Nga ${ }^{1}$, Ha Thi Thuy ${ }^{1}$, Nguyen Kieu Bang Tam ${ }^{2}$, Dao Thi Hong $\mathrm{Van}^{3}$

${ }^{1}$ Department of Biological Environment, Institute of Agricultural Environment, Km Nol, Dai Mo, Phu Do, Nam Tu Liem, Ha Noi; ${ }^{2}$ Department of Ecological Environment, Faculty of Environmental Sciences, HUS, 334 Nguyen Trai, Thanh Xuan, Ha Noi; ${ }^{3}$ Faculty of Biotechnology, Ha Noi Open University, 101B Nguyen Hien Street, Hai Ba Trung, Ha Noi, Vietnam

\begin{abstract}
Validamycin A (Val-A) is an aminoglycoside's antibiotic with anti-fungal activity. Val-A synthesized by Streptomyces hygroscopicus strain depending on the growth and development of this actinomyces. In this study, the effects of $\mathrm{Mn}$ and $\mathrm{Zn}$ on the antifungal activity and biomass of the Streptomyces hygroscopicus were conducted. The results showed that micronutrients $\mathrm{Mn}, \mathrm{Zn}$ had significant effects on biomass as well as antifungal activity of strain Streptomyces hygroscopicus-DA15. With the addition of $\mathrm{Mn}$ at a concentration of $1 \mu \mathrm{g} / 1$ of the nutrient medium, biomass of Streptomyces hygroscopicus was $2.85 \pm 0.02 \mathrm{~g} / \mathrm{ml}$, the anti-fungal Rhizoctoniasolani (R. solani) round diameter reached $3.5 \pm 0.2 \mathrm{~cm}$. With the addition of $\mathrm{Zn}=3 \mu \mathrm{g} / \mathrm{l}$ of the nutrient medium, biomass of Streptomyces hygroscopicus DA15 was $4.5 \pm 0.02 \mathrm{~g} / \mathrm{ml}$, the anti-fungal R. solani round diameter reached $3.4 \pm 0.2 \mathrm{~cm}$.
\end{abstract}

Validamycin A (val-A) là một loại kháng sinh có khả năng kháng nấm, được tổng hợp bởi xạ khuẩn Streptomyces hygroscopicus và phu thuộc vào quá trình sinh truởng, phát triển của xạ khuẩn. Bài báo này đánh giá ảnh hưởng của nguyên tố vi lượng $M n$, Zn đến hoạt tính kháng nấm Rhizoctonia solani (R. solani) và sinh khối của chủng Streptomyces hygroscopicus DA15. Khi bổ sung Mn vào môi trưòng nuôi cấy với nồng độ $1 \mu \mathrm{g} / \mathrm{l}$, sinh khối của Streptomyces hygroscopicus-


nuôi cấy với hàm luợng $Z n=3 \mu \mathrm{g} / \mathrm{l}$, sinh khối của Streptomyces hygroscopicus DA15 đạt $4,5 \pm 0,02 \mathrm{~g} / \mathrm{ml}$ và đưòng kính vòng kháng nấm đạt $3,4 \pm 0,2 \mathrm{~cm}$.

Keywords: Antifungal activity, biomass, microelements, Streptomyces hygroscopicus, validamycin A (Val-A)

\section{Introduction}

For a long time, plant protection chemicals have been used extensively by farmers to deal with plan diseases due to its rapid result, simple procedure and convenience. However, residues of plant protection chemicals are causing severe damage to the environment, affecting ecosystems and human health. Therefore, scientists are looking for bioproducts to prevent plant diseases with environmental friendly characteristics such as selective elimination, easy to decompose and safe to the environment.
In Viet Nam, one of the safest plant protection products widely used for fungicides is Validamycin. The most effective is validamycin isomerism A. Validamycin A (val-A) is an aminoglycoside antibiotic that has been synthesized primarily by Streptomyces hygroscopicus var. limoneus and S. hygroscopicus subsp. jinggangensis 5008 [2]. Because of the high efficiency of fungus prevention as well as safety for humans and animals, Val-A becomes one of the most important antibiotic and widely used in agriculture. As Val-A recovery efficiency is not high, 
therefore the most effective Val-A recovery solution must be found. One approach is to select appropriate nutrients for culture medium.

Nutrients are materials that are derived from the environment and are used for the growth and metabolism of microorganisms. Microorganisms require nutrients very different in origin, chemical composition as well as volume needed. The bulk of nutrient is required in large quantities to maintain cellular structure and metabolism of microorganisms. With micronutrients, microorganisms only need a very small amount, about $10^{-8}-10^{-6} \mathrm{~mol} / 1$ on culture medium but they play an important role in enzyme activation [1]. Some trace elements are manganese, zinc, cobalt, molybdenum, copper and nickel.

If the micronutrient is deficient in microbial growth, the physiological activity of the microorganism is reduced. Because the nutrient requirements of microorganisms are not the same, the concept of trace elements is relatively significant. Microorganisms often receive micronutrient from natural organic nutrients, inorganic chemicals, tap water or even from glass implanted devices. Only in special cases microelements should be added to microbiological culture mediums, because many micronutrients are heavy metals, their excess is harmful to microorganisms.

For Streptomyces hygroscopicus, trace elements play a very important role in the synthesis of antibiotics. Therefore, "Study on the effects of some microelements on antifungal activity and biomass of the Actinomyces which produces Validamycin-A" was carried out.

\section{Materials and methods}

\subsection{Materials}

Table 1. The proportion of micronutrients added in the study

\begin{tabular}{ccc}
\multirow{2}{*}{$\begin{array}{c}\text { Concentration } \\
\text { of micronutri- } \\
\text { ent }(\boldsymbol{\mu g} / \mathbf{l})\end{array}$} & \multicolumn{2}{c}{$\begin{array}{c}\text { Compound volume corresponds to } \\
\text { micronutrient concentration(g/l) }\end{array}$} \\
\cline { 2 - 3 } $\mathbf{M n C l}_{\mathbf{2 . 4}} \mathbf{~ H}_{\mathbf{2}} \mathbf{O}$ & $\mathbf{Z n S O}_{\mathbf{4}}, \mathbf{7} \mathbf{H}_{\mathbf{2}} \mathbf{O}$ \\
\hline 1 & 0.004 & 0.009 \\
3 & 0.013 & 0.014 \\
5 & 0.021 & 0.023 \\
7 & 0.030 & 0.032 \\
10 & 0.043 & 0.045
\end{tabular}

- DA15 strain of Actinomyces Streptomyces hygroscopicus

- Fungus: Rhizoctoniasolani.

- Culture medium: soybean: 20g; mantoza: 20g; agar: $12 \mathrm{~g}$, fresh water: 1 litter.

- Gause medium liquid I (g/l): starch: $20 \mathrm{~g} ; \mathrm{K}_{2} \mathrm{HPO}_{4} 0.5 \mathrm{~g}$; $\mathrm{MgSO}_{4} .7 \mathrm{H}_{2} \mathrm{O} 0.5 \mathrm{~g} ; \mathrm{NaCl} 0.5 \mathrm{~g} ; \mathrm{KNO}_{3} 0.5 \mathrm{~g} ; \mathrm{FeSO}_{4}$ 0.01g; $\mathrm{pH}=7.4$.

- A1 medium: saccarose, 1.0; meat extract, 5.0; pepton, 10; agar, 8; pH 7.0.
- A2 medium:saccarose, 2.5; pepton, 4.5; $\mathrm{NaCl}, 1$; agar, 12.0; pH 7.0.

- Micronutrients: $\mathrm{MnCl}_{2} \cdot 4 \mathrm{H}_{2} \mathrm{O} ; \mathrm{ZnSO}_{4} \cdot 7 \mathrm{H}_{2} \mathrm{O}$ are added to the Gauze medium from $1-10 \mu \mathrm{g} / 1$ as table 1 .

\subsection{Research Methods}

\section{Determination of antibiotic activity [3]}

R. solani fungus was fermented in Hansen medium for 48 hours. $1 \mathrm{ml}$ of $R$. solani mass after fermentation was added to $20 \mathrm{ml}$ of $\mathrm{A} 1$ medium agar, incubated at $27^{\circ} \mathrm{C}$ for 48 hours. Then, $25 \mathrm{ml}$ of A 2 medium agar were covered on the petri dish surface. A hole in the center of petri dish was created with a diameter of $1 \mathrm{~cm}$, then drip into the hole the standard antibiotic liquid solution and the sample after centrifuged to remove the biomass. The petri dishes were placed at $4-5^{\circ} \mathrm{C}$ during 4 hours for antibiotic diffusion to the medium agar, after that the dishes were kept at $28^{\circ} \mathrm{C}$ and measured the antibiotic ring after 24 hours.

Selection of micronutrient concentrations in the nutrient medium

Micronutrient ( $\mathrm{Mn}$ and $\mathrm{Zn}$ ) were added in the form of their compounds $\left(\mathrm{MnCl}_{2} \cdot 4 \mathrm{H}_{2} \mathrm{O} ; \mathrm{ZnSO}_{4} \cdot 7 \mathrm{H}_{2} \mathrm{O}\right)$ into the culture medium (Gause I) with concentration of 1-10 $\mu \mathrm{g} / \mathrm{l}$. Grow Actinomyces in culture medium at $200 \mathrm{rpm}$ shaking condition, with a time of 96 hours at $37^{\circ} \mathrm{C}$. Antibiotic activity was assessed by the anti-fungus $R$. solani activities of Actinomyces.

\section{Determination of biomass volume [6]}

By method of drying to constant volume: Centrifuge for biomass cell separation, rinse cells and then dry them in oven and weigh dry weight.

\section{Results and discussion}

\subsection{Physiological and morphological characteristics of $S$. hygroscopicus DA15}

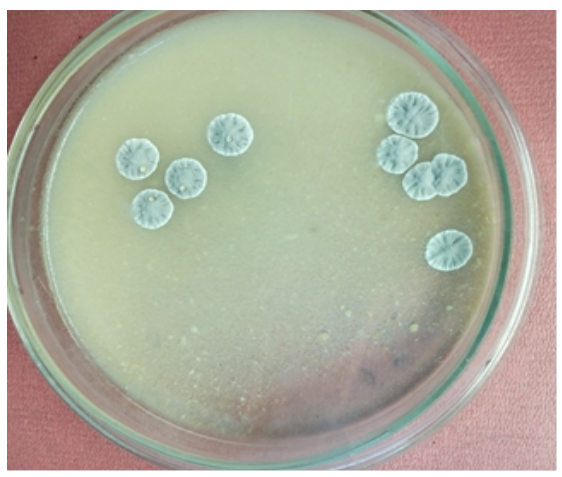

Figure 1. Colonies of S. hygroscopicus DA15 on solid medium after 4 days of cultivation

S. hygroscopicus was cultured on oat jelly. Results of morphological studies show that: Colonies of S.hygroscopicus DA15 are grayish brown, rounded, 
serrated, the size after cultivation for 4 days is about $8-10 \mathrm{~mm}$, the surface is convex, rough, pyramid shape, especially transparent appearance on the surface (after 3 days of cultivation). The results are identical to those of Thompson CJ et al. (1987) [9].

The growth curve of Streptomyces hygroscopicus DA15 is shown in Figure 2.

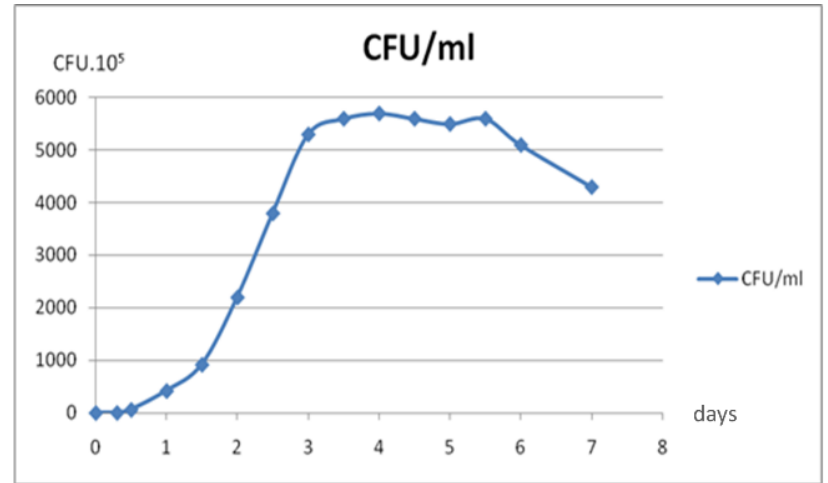

Figure 2. The growth curve of Streptomyces hygroscopicus DA15

Figure 2 showed 4 phases when S. hygroscopicus DA15 was cultured on liquid medium: Adaptation phase occurs between 0 hours and 8 hours after cultivation; Logarithmic phase (lag) occurs during 8 hours to 72 hours; Phase equilibrium occurs at 72 - 120 hours; Recessionary phase begins after 120 hours of culture. In the equilibrium phase, the density of Streptomyces hygroscopicus DA15 is $>5.10^{8} \mathrm{CFU} / \mathrm{ml}$. In antibiotic production, antibiotic recovery time is very important. 4 day-fermentation is the best time to recover biomass. Biomass of $S$. hygroscopicus was higher: $2.2 \pm 0.1(\mathrm{~g} / \mathrm{ml})$. This result is the basis for further research.

\subsection{Effect of Mn on biomass and antibiotic production of $S$. hygroscopicus DA15 strain}

Experiment was carried out with supplement of $\mathrm{Mn}$ in the form of compound $\mathrm{MnCl}_{2} .4 \mathrm{H}_{2} \mathrm{O}$ with concentrations of $1 ; 3 ; 5 ; 7(\mu \mathrm{g} / 1)$. The results are showed in the table 2 .

Table 2. Effect of Mn supplement for biomass production and antibiotic activity of the Streptomyces hygroscopicus-DA15 strain

\begin{tabular}{ccc}
$\begin{array}{c}\text { Mn } \\
\text { concentration } \\
(\boldsymbol{\mu g} / \mathbf{l})\end{array}$ & $\begin{array}{c}\text { Antifungal } \boldsymbol{R} \text {. } \\
\text { solani round } \\
\text { diameter } \\
(\mathbf{c m})\end{array}$ & $\begin{array}{c}\text { DA15 - Streptomyces } \\
\text { hygroscopicus } \\
\text { biomass }(\mathbf{g} / \mathbf{m l})\end{array}$ \\
\hline 0 & $2.6 \pm 0.1$ & $2.2 \pm 0.01$ \\
1 & $3.5 \pm 0.2$ & $2.85 \pm 0.02$ \\
3 & $3.0 \pm 0.2$ & $1.74 \pm 0.02$ \\
5 & $2.9 \pm 0.1$ & $1.7 \pm 0.01$ \\
7 & $2.5 \pm 0.2$ & $1.34 \pm 0.02$ \\
10 & $2.1 \pm 0.2$ & $1.56 \pm 0.01$
\end{tabular}

The results in Table 2 showed that, with the addition of $\mathrm{Mn}$ at a concentration of $1 \mu \mathrm{g} / 1$ of the nutrient medium, biomass of $S$. hygroscopicus was $2.85 \pm 0.02 \mathrm{~g} / \mathrm{ml}$, the anti
$R$. solani round diameter reached $3.5 \pm 0.2 \mathrm{~cm}$. Whereas in the control formula (concentration $\mathrm{Mn}=0$ ), the anti $R$. solani round diameter was $2.5 \pm 0.1 \mathrm{~cm}$ and the biomass of the strains was $2.2 \pm 0.01 \mathrm{~g} / \mathrm{ml}$. The results showed that with the addition of $\mathrm{Mn}$ at a concentration of $1 \mu \mathrm{g} / \mathrm{l}$ of the nutrient medium, the inhibition activity $R$. solani of $S$. hygroscopicus increased, biomass of $S$. hygroscopicus was higher than in the case of no supplement. The results showed that when Mn concentration increased from 3, 5 to $7 \mu \mathrm{g} / 1$ of the nutrient medium, the activity and biomass of $S$. hygroscopicus DA15 decreased gradually compared with control. The same research was also carried out by Kishimoto et al. (1996 and 1997) on the importance of ferrous ions for the growth and antibiotic production by Streptoverticillium rimofaciens [7,8]. Mansour et al. (1996) showed that manganese ions enhanced growth and granaticin production in $S$. violaceolatus [5].

\subsection{Effect of $\mathrm{Zn}$ on fermentation and antibi- otic production of the $S$. hygroscopicus-DA15 strain}

An experiment with supplement of $\mathrm{Zn}$ in the form of compound $\mathrm{ZnSO}_{4} 7 \mathrm{H}_{2} \mathrm{O}$ with increasing concentration: 0 ; $1 ; 3 ; 5 ; 7 ; 10(\mu \mathrm{g} / 1)$ was carried out. The results are showed in the table 3 .

Table 3. Effect of $\mathrm{Zn}$ supplement for biomass production and antibiotic activity of the $S$. hygroscopicusDA15 strain

\begin{tabular}{ccc}
$\begin{array}{c}\mathbf{Z n} \\
\text { concentration } \\
(\boldsymbol{\mu g} / \mathbf{l})\end{array}$ & $\begin{array}{c}\text { Antifungal } \boldsymbol{R} \text {. } \\
\text { solani round } \\
\text { diameter }(\mathbf{c m})\end{array}$ & $\begin{array}{c}\text { S. hygroscopicus } \\
\text { biomass } \\
(\mathbf{g} / \mathbf{m l})\end{array}$ \\
\hline 0 & $2.5 \pm 0.1$ & $2.3 \pm 0.02$ \\
1 & $3.1 \pm 0.2$ & $3.53 \pm 0.02$ \\
3 & $3.4 \pm 0.2$ & $4.5 \pm 0.02$ \\
5 & $2.8 \pm 0.2$ & $2.32 \pm 0.01$ \\
7 & $2.9 \pm 0.2$ & $2.51 \pm 0.02$ \\
10 & $2.5 \pm 0.1$ & $2.0 \pm 0.01$
\end{tabular}

The results in Table 3 showed that, at different concentrations of $\mathrm{Zn}$, it has different effects on the biomass of $S$. hygroscopicus and antifungal $R$. solani of DA15.

With the addition of $\mathrm{Zn}=3 \mu \mathrm{g} / \mathrm{l}$ of the nutrient medium, biomass of $S$. hygroscopicus was $4.5 \pm 0.02 \mathrm{~g} / \mathrm{ml}$, the antifungal $R$. solani round diameter reached $3.4 \pm 0.2 \mathrm{~cm}$. Whereas in the control formula (concentration $\mathrm{Zn}=0$ ), the round diameter was $2.5 \pm 0.1 \mathrm{~cm}$ and the biomass of the strain was $2.3 \pm 0.02 \mathrm{~g} / \mathrm{ml}$. The results showed that with the addition of $\mathrm{Zn}$ at a concentration of $3 \mu \mathrm{g} / \mathrm{l}$ of nutrient medium, the inhibition activity $R$. solani of $S$. hygroscopicus increased and the biomass of S. hygroscopicus was higher than in the case of no supplement. When $\mathrm{Zn}$ concentration increased from 5, 7 to $10 \mu \mathrm{g} / 1$ of the nutrient medium, the activity and biomass of $S$. hygroscopicus DA15 decreased gradually compared with control.

The results of this study coincide with the research results of Maha A et al. (2001) [4]. 


\section{Conclusion}

The micronutrients $\mathrm{Mn}$ and $\mathrm{Zn}$ have influenced on the biomass as well as the bioactivity of $S$. hygroscopicus DA15: With the addition of $\mathrm{Mn}$ at a concentration of $1 \mu \mathrm{g} / 1$ of the nutrient medium, biomass of Streptomyces hygroscopicus was $2.85 \pm 0.02 \mathrm{~g} / \mathrm{ml}$, the anti $R$. solani round diameter reached $3.5 \pm 0.2 \mathrm{~cm}$. With the addition of $\mathrm{Zn}=3 \mu \mathrm{g} / 1$ of the nutrient medium, biomass of $S$. hygroscopicus DA15 was $4.5 \pm 0.02 \mathrm{~g} / \mathrm{ml}$, the anti $R$. solani round diameter reached $3.4 \pm 0.2 \mathrm{~cm}$.

The results of the study were significant for the study of the Val A recovery process from Streptomyces hygroscopicus DA15, which is used as the production material to produce biological protective preparations.

Recommendation: Further research on the potential to produce biological products from the $S$. hygroscopicus DA15 is needed with the goal of replacing and limiting plant protection chemicals in agricultural production.

\section{References}

[1] Nguyen Lan Dung, Bui Viet Ha (2009). Microbiology Part I (In Vietnamese). Scientific and technical Publishing House, Ha Noi, p. 564-586.

[2] Iwasa T, Higashide E, Yamamoto H, Shibata M (1970). Studies on validamycins, new antibiotics. II. Production and biological properties of validamycins A and B. J. Antibiot (Tokyo) 24, 107-113

[3] Iwasa T, Yamamoto H, Shibata M (1970). Studies on validamycins, new antibiotics. I. Streptomyces hygroscopicus var. limoneusnov. var., validamycinproducing organism. J. Antibiot, 23(12), p. 595-602.

[4] Maha A. Hassan, Moustafa Y. El-Naggar and Wafa Y. Said (2001). Physiological factors affecting the production of an antimicrobial substance by Streptomyces violatus in batch cultures. Egyptian Journal of Biology, 3, 1-10.

[5] Mansour FA, El-Shirbiny SA \& El-Metwaly NA (1996) Demethyltetracycline biosynthesis by Streptomyces aureofaciens Sub-species viridulans as influenced by medium composition. Egyptian Journal of Microbiology 31, 221-235.

[6] Nam Sun Wang (2009). Experiment no.9C measurements of cell biomass concentration. Department of Chemical \& Biomolecular Engineering University of Maryland College Park, MD, 2074-2111.

[7] Kishimoto K, Park YS, Okabe M \& Akiyama S (1996) Effect of phosphate ion on mildiomycin production by Streptoverticillium rimofaciens. Journal of Antibiotics 49, 775-780.

[8] Kishimoto K, Park YS, Okabe M \& Akiyama S (1997) Effect of ferrous ion on amino acid metabolism in mildiomycin production by Streptoverticillium rimofaciens. Journal of Antibiotics 50, 206-211.

[9] Thompson CJ, Movva NR, Tizard R, Crameri R, Davies JE, Lauwereys M, Botterman J. EMBO J (1987). Characterization of the herbicide-resistance gene bar from Streptomyces hygroscopicus, 6(9), 2519-2523. 